\title{
PENGARUH SUHU PENGERINGAN KULIT BAGIAN LUAR DAN BAGIAN DALAM MANGGIS (Gracinia mangostana, L.) TERHADAP KANDUNGAN PROKSIMAT, ALKALOID DAN FLAVONOID
}

\author{
I Gusti Ayu Manik Widhyastini ${ }^{1)^{*}}$ \\ ${ }^{1)}$ Program Studi Biologi FMIPA Universitas Nusa Bangsa Bogor \\ Jl. KH Soleh Iskandar KM 4 Cimanggu Tanah Sareal, Bogor 16166 \\ *email : widhyastini0508@yahoo.com
}

\author{
ABSTRACT \\ The Effect of Drying on The Outer and Inner Skin of Mangosteen (Gracinia \\ mangostana, L.) for the Content of Proximate Analysis, Alkaloid and Flavanoid
}

\begin{abstract}
Mangosteen (Garcinia mangostana,L.), is considered to be one of the leading exports commodity in which the peel has the major part (60,82\% from the total weight of the fruit), the flesh of the fruit is the second $(35,51)$, the rest are the leaf sheaths $(3,67)$. The peel of the mangosteen is rich in antioxidant which is useful for human health and this potential hasn't been used widely. The use of the peel of mangosteen need to be furtherly reviewed.The preliminary research aimed to figure out the optimum temperature for drying the outer and the inner skin of the mangosteen as a test to obtain the content of proximate analysis, alkaloid and flavanoid. The results of the proximate test was obtained that the water content of the outer skin with temperature of $70^{\circ} \mathrm{C} ; 80^{\circ} \mathrm{C} ; 90^{\circ} \mathrm{C} ; 100^{\circ} \mathrm{C}$, was between $7 \%$ to $10 \%$ while the water content for the inner skin was between $11 \%$ to $12 \%$, dry mass of $1 \%$ to $3 \%, N$ content between $0,1 \%$ until $0,5 \%$, carbohydrate content between $1 \%$ until 2,5\%. The results of the alkaloid test showed that all of the experiment treatments revealed positive results as well as the flavonoid test. The highest content of alkaloid and flavonoid was obtained at a temperature of $80^{\circ} \mathrm{C}$ to dry the outer skin of the mangosteen.
\end{abstract}

Key words: proximate analysis, antioxidant, alkaloid and flavonoid

\begin{abstract}
ABSTRAK
Manggis (Garcinia mangostana,L.), merupakan salah satu primadona ekspor yang menjadi andalan Indonesia Komponen terbesar dari buah manggis adalah kulit buah (60,82\% dari berat buah utuh),daging buah merupakan komponen yang kedua $(35,51 \%)$, sisanya adalah komponen daun kelopak $(3,67 \%)$. Kulit buah manggis, kaya akan senyawa antioksidan yang sangat bermanfaat bagi kesehatan manusia dan potensi ini belum dimanfaatkan secara luas.Pemanfaatan kulit buah manggis perlu dikaji lebih lanjut.Penelitian pendahuluan yang bertujuan untuk mengetahui suhu pengeringan optimal padakulit bagian luar dan kulit bagian dalam manggis terhadap kandunganproksimat, alkaloid dan flavonoid. Hasil uji proksimat diperoleh bahwa kadar air untuk kulit bagian luar masing-masing dengan suhu pengeringan $70^{\circ} \mathrm{C} ; 80^{\circ} \mathrm{C} ; 90^{\circ} \mathrm{C} ; 100^{\circ} \mathrm{C}$ adalah berkisar dari $7 \%$ sampai $10 \%$ sedangkan kadar air pada kulit bagian dalam adalah berkisar dari $11 \%$ sampai $12 \%$, kadar abu $1 \%$ sampai $3 \%$, kadar $\mathrm{N}$ berkisar antara $0,1 \%$ sampai $0,5 \%$, kadar Karbohidrat berkisar antara $1 \%$ sampai $2,5 \%$. Hasil uji alkaloid menunjukkan bahwa semua perlakuan menunjukkan hasil positif demikian juga dengan hasil uji flavonoid. Kandungan alkaloid dan flavonoid terbanyak diperoleh pada pengeringan $80^{\circ} \mathrm{C}$ untuk kulit bagian luar dari manggis.
\end{abstract}

Kata kunci: proksimat, antioksidan, alkaloid dan flavonoid

\section{PENDAHULUAN}

Manggis (Garcinia mangostan,L) merupakan buah tropis yang tumbuh terutama di tempat yang panas, iklim lembab di Asia Tenggara seperti Thailand, Malaysia, Singapura, Vietnam, dan Indonesia. Di Asia Tenggara, kulit atau pericarp buah manggistelah digunakan untuk tujuan pengobatan dari generasi ke generasi (Wong,C.,2006).

Penelitian-penelitian yang telah dilakukan menunjukkan bahwa kulit manggis kaya akan senyawa antioksidan yang sangat bermanfaat bagi kesehatan manusia. Kulit buah ditemukan mengandung senyawa alpha-Mangostin, beta-Mangostin, garcinone $\mathrm{B}$, dan $\mathrm{E}$ 
garcinone, yang secara kolektif disebut xanthones. Pemanfaatan kulit buah manggis hingga saat ini masih terbatas pada penyamakan kulit, pewarna tekstil dan pengobatan tradisional,seperti untuk pengobatan diare, infeksi kantung kemih dan potensi ini perlu dimanfaatkan secara luas.

Buah manggis hanya tersedia 3-4 bulan dalam setahun sehingga banyak industri pengolahan manggis sulit memperoleh bahan baku pada saat di luar musim. Penyimpanan manggis dalam kondisi dingin memerlukan biaya yang tinggi dan hanya mampu menambah umur simpan maksimal 3 minggu. Masalah lainnya, antioksidan dalam kondisi kadar air tinggi akan mudah berubah dan rusak. Indonesia sebagai produsen manggis terbesar di dunia, baik dari sisi produksi maupun luas panen. (Litbang Deptan ,2010).Cara pemanenan dan penanganan bahan setelah panen merupakan periode kritis yang sangat menentukan kualitas dan kuantitas hasil tanaman Panen merupakan salah satu rangkaian tahapan dalam proses budidaya tanaman obat.

Pasca panen merupakan kelanjutan dari proses panen terhadap tanaman budidaya, untuk membuat bahan hasil panen tidak mudah rusak dan memiliki kualitas yang baik serta mudah disimpan untuk proses selanjutnya, (Sembiring, 2007).Simplisia kulit buah mangga (Garcinia mangostana L.) mengandung senyawa golongan flavonoid, saponin, tanin, steroid/triterpenoid dan kuinon serta unsur natrium, kalium, magnesium, kalsium, besi, zink dan tembaga, (Marisi, dkk. 2007).

Pengeringan merupakan suatu cara pengawetan atau pengolahan pada bahan dengan cara mengurangi kadar air, sehingga proses pembusukan dapat terhambat. Waktu dan suhu pengeringan perlu diperhatikan untuk menghasilkan simplisia tanaman obat yang bermutu, sehingga memiliki nilai jual yang tinggi.
Penelitian terhadap pengaruh suhu pengeringan merupakan penelitian pendahuluan untuk memperoleh simplisia kulit manggis yang mempunyai kualitas yang baik perlu dilakukan. Variasi suhu pengeringan terhadap kulit manggis bagian dalam dan bagian luar, yang digunakan pada penelitian ini adalah $70^{\circ} \mathrm{C}, 80^{\circ} \mathrm{C}, 90^{\circ} \mathrm{C}$ dan $100^{\circ} \mathrm{C}$ selama 24 jam, kemudian dilakukan analisis kadar proksimat, alkaloid dan flavonoid yang dengan ekstrak etanol.

\section{BAHAN DAN METODE}

\section{Bahan}

Bahan-bahan yang digunakan antara lain, buah manggis (Garcinia Mangostana), etanol $95 \%$, ammonia $25 \%$ (Merck), Kloroform (smart), Petroleum Eter (Smart), $\mathrm{HCl} 37 \%$ (Merck),

\section{Alat \\ Pereaksi Dragendroff, pereaksi Mayer, Pereaksi Wagner, pereaksi Liebermann-Burchard, serbuk magne- sium, amilalkohol, asam alkohol .}

\section{Metode}

Rangkaiaan penelitian dimulai dengan melakukan uji kesesuaian species tanaman sampel melalui determinasi buah manggis, Determinasi dilakukan di Pusat Penelitian BiologiLembaga Ilmu Pengetahuan Indonesia (LIPI) di Cibinong, Bogor, kemudian dilanjutkan dengan preparasi simplisia, analisis proksimat ( kadar air, kadar abu, kadar nitrogen total, kadar protein, kadar lemak kasar), pembuatan ekstrak kulit dalam dan luar manggis dengan etanol 95\%, Uji Fitokimia (identifikasi senyawa alkaloid dan Flavonoid), Zhang,atc all.2009. 

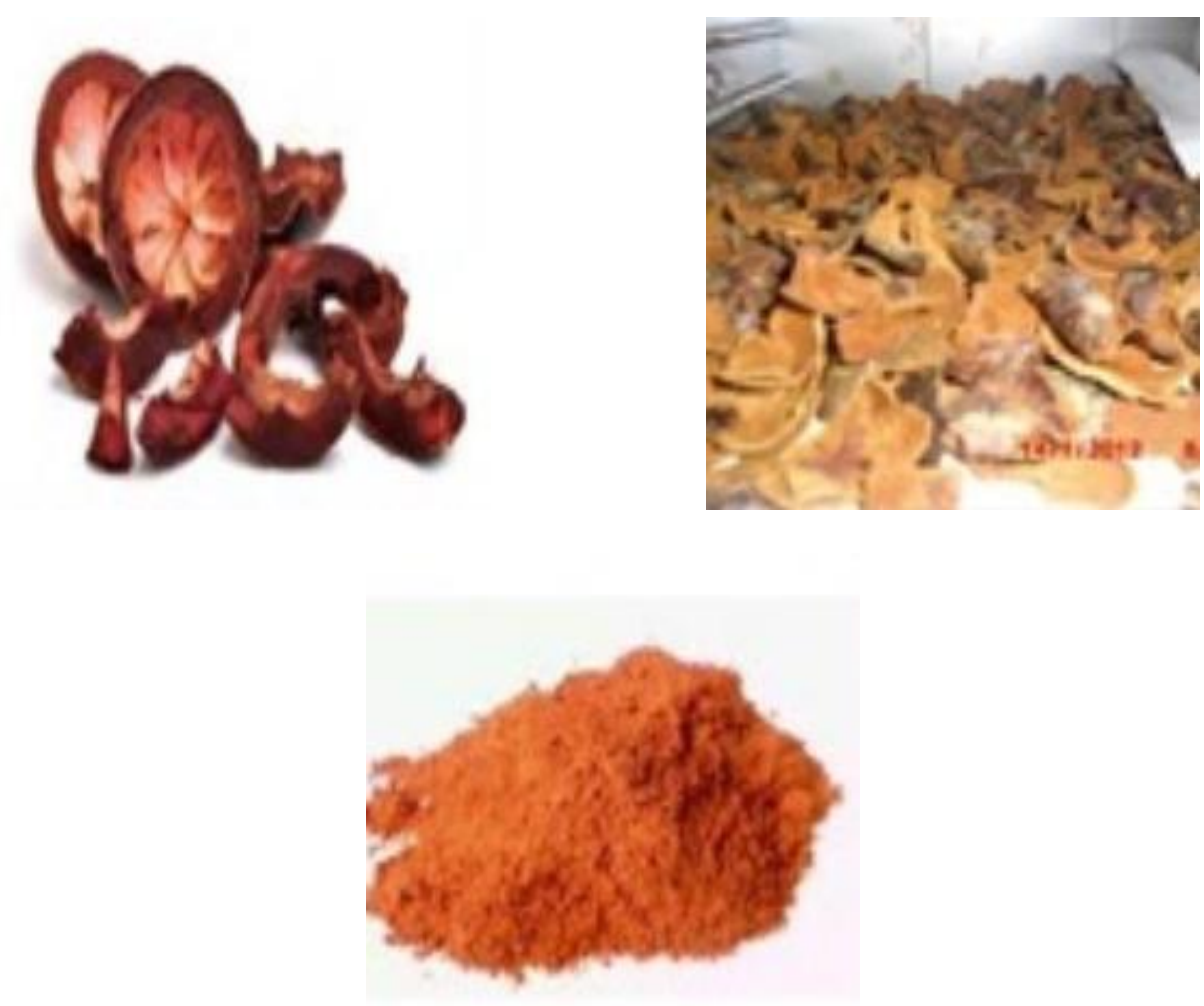

Gambar 1. Kulit Manggis Sebelum dan Setelah Dihaluskan

Penelitian ini menggunakan menggunakan metode kualitatif untuk uji kadar alkaloid dan flavonoid. Endapan merah bata (+), Mayer Endapan putih $(+)$, Wagner Endapan coklat $(+)$, menunjukkan adanya senyawa alkaloid. Terbentuk warna merah, kuning atau jingga pada lapisan amil alkohol, adanya senyawa flavonoid.

Buah manggis yang digunakan sebagai sampel penelitian diperoleh dari Pasar Anyar Bogor. Buah manggis yang digunakan adalah buah yang sudah tua atau matang siap konsumsi, ditandai dengan warna kulit buah manggis unggu, buahnya sudah wangi dan rasanya manis.

Buah manggis yang sudah matang dibelah pisahkan antara kulit dalam dan luarnya, kulit dalam dan luar masingmasing diiris tipis-tipis, kemudian dioven sesuai suhu yaitu $70^{\circ} \mathrm{C}, 80^{\circ} \mathrm{C}$, $90^{\circ} \mathrm{C}, 100^{\circ} \mathrm{C}$ selama 48 jam. Selanjutnya kulit manggis yang sudah kering digiling sehingga menjadi simplisia serbuk lalu di ayak dengan mesh 16, disajikan pada Gambar 1. Simplisia disimpan dalam wadah bersih dan tertutup rapat.

Proses ekstraksi dilakukan dengan metode maserasi dengan etanol $96 \%$. Perbandingan jumlah simplisia yang akan diekstrak dan etanol $96 \%$ sebesar $1: 10$ ( 100 gram simplisia diekstraksi dengan $1000 \mathrm{ml}$ etanol 96\%). Campuran simplisia dan pelarut direndam selama 6 jam sambil diaduk dengan stirrer, kemudian dibiarkan selama 24 jam. Setelah proses maserasi selesai campuran disaring dengan kertas saring kasar, lalu filtrat disimpan pada Erlenmeyer asah. Sedangkan ampas dimaserasi kembali dengan prosedur yang sama sebanyak 2 kali. Kemudian filtrat diuapkan dengan rotary evaporator hingga terbentuk ekstrak tidak terlalu kental, lalu tuangkan dalam cawan, uapkan kembali diatas water bath sampai kental, lalu timbang (Depkes, 2004).

Analisis proksimat merupakan suatu metode analisis kimia untuk mengidentifikasi kandungan zat 
makanan dari suatu bahan sebagai dasar analisis lebih lanjut.

Kadar air, cawan porselin dibersihkan dan dipanaskan dalam oven, lalu ditimbang sebagai bobot kosong. Contoh yang telah dihomogenkan ditimbang sebanyak $3 \mathrm{~g}$ dalam cawan dinyatakan sebagai bobot awal, kemudian cawan tersebut dimasukkan ke dalam oven dengan suhu $105^{\circ} \mathrm{C}$ selama 3-5 jam. Setelah proses pengeringan, cawan dikeluarkan dari oven dan dimasukkan ke dalam desikator, dan setelah dingin ditimbang dan dikeringkan kembali dalam oven sampai diperoleh bobot tetap sebagai bobot akhir.

Kadar abu, cawan yang telah dibersihkan dipanaskan dalam tanur pada suhu $100^{\circ} \mathrm{C}$ selama 2 jam lalu ditimbang sebagai bobot kosong. Contoh yang telah diuapkan ditimbang teliti $+1 \mathrm{~g}$ dalam cawan dan dinyatakan sebagai bobot awal, kemudian cawan tersebut dimasukkan ke dalam tanur suhu $600^{\circ} \mathrm{C}$ selama 5 jam. Setelah pemanasan cawan dimasukkan ke dalam desikator, dan setelah dingin ditimbang dan dipanaskan beberapa kali sampai diperoleh bobot tetap sebagai bobot akhir.

Kadar protein,sampel ditimbang secara teliti sebanyak $200 \mathrm{mg}$, lalu dimasukkan ke dalam labu Kjeldhal. Selanjutnya ditambahkan selen dan 10 $\mathrm{ml}$ asam sulfat pekat dan didestruksi pada pemanas selama 2-3 jam atau sampai larutan menjadi jernih. Setelah proses destruksi lalu dipindahkan ke dalam labu destilasi kemudian diperiksa kandungan nitrogennya dengan menggunakan alat kjeltek.

Kadar lemak kasar, labu penyari kosong dikeringkan dalam oven suhu $105^{\circ} \mathrm{C}$ selama 60 menit, dinginkan dan ditimbang (a) ditimbang contoh sebanyak 5 gram (b) dimasukan kedalam selongsong penyari, kemudian selongsong penyari dimasukan kedalam Soxlet, selongsong penyari $(250 \mathrm{ml})$ dimasukan kedalam Soxlet, disari dengan $250 \mathrm{ml}$ Petroleum Eter, diatas penangas selama 4 jam. Setelah 4 jam, kemudian larutan tersisa (P.E) dimasukan dalam labu penyari sampai soxlet kering. Uapkan dalam Heatle Mantle, diangka 2 biarkan 15 menit, atau sampai larutan kering. Labu penyari dikeringkan dalam oven suhu $105^{\circ} \mathrm{C}$ selama 1 jam, dinginkan dalam desikator, ditimbang dan dicatat. Kadar lemak kasar dihitung (AOAC 1995).

\section{HASIL DAN PEMBAHASAN}

Hasil analisis proksimat kulit luar dan kulit bagian dalam buah manggis (Garcinia mangostanaL.) Pada pelarut Etanol $96 \%$ ditunjukkan pada tabel 1 dan pada Gambar 2.

Hasil uji kandungan proksimat menunjukkan perbedaan yang bervariasi, kadar air untuk kulit bagian luar (A,B,C,D) diperoleh hasil $7.8 \%$ hingga $9,8 \%$ yang sesuai dengan persyaratan sebagai Simplisia Terstandar Tanaman Obat yaitu 8\%-10\%, ( Sembiring,2007). Sedangkan kadar air pada kulit bagian dalam (E,F,G,H) diperoleh hasil dengan kadar air yang lebih tinggi berkisar dari $11 \%$ hingga $12 \%$, kemungkinan disebabkan oleh kondisi awal bahan yang lebih basah di bandingkan dengan kulit bagian luar. Untuk kadar abu, lemak karbohidrat diperoleh hasil yang sangat bervariasi sangat di pengaruhi oleh kandungan mineral bahan baku. 
Tabel 1. Analisis Proksimat Kulit Luar dan Kulit Bagian Dalam Buah Manggis (Garcinia mangostanaL.) pada Pelarut Etanol $96 \%$

\begin{tabular}{cccccc}
\hline SAMPEL & $\begin{array}{c}\text { \% } \\
\text { KADAR } \\
\text { AIR }\end{array}$ & $\begin{array}{c}\text { \% } \\
\text { KADAR } \\
\text { ABU }\end{array}$ & $\begin{array}{c}\text { \% } \\
\text { NITROGEN } \\
\text { TOTAL }\end{array}$ & $\begin{array}{c}\text { \% } \\
\text { KARBOHIDRAT }\end{array}$ & $\begin{array}{c}\text { \% } \\
\text { KADAR } \\
\text { LEMAK }\end{array}$ \\
\hline $\mathbf{A}$ & 7,765 & 1,997 & 0,2772 & 1,590 & 0,8674 \\
$\mathbf{B}$ & 9,362 & 2,308 & 0,4228 & 2,105 & 0,4818 \\
$\mathbf{C}$ & 9,762 & 2,614 & 0,4956 & 1,408 & 1,3373 \\
$\mathbf{D}$ & 9,681 & 1,859 & 0,2574 & 1,705 & 1,9195 \\
$\mathbf{E}$ & 11,033 & 1,422 & 0.4200 & 1,568 & 0.8237 \\
$\mathbf{F}$ & 11,788 & 2,108 & 0,2718 & 2,039 & 0,8595 \\
$\mathbf{G}$ & 11,118 & 5,883 & 0,3864 & 1,590 & 1,3836 \\
$\mathbf{H}$ & 24,542 & 2,109 & 0,3136 & 2,034 & 1,5849 \\
\hline
\end{tabular}

Ket. A : Kulit luar manggis suhu $70^{\circ} \mathrm{C}$,

$\mathrm{B}$ : Kulit luar manggis suhu $80^{\circ} \mathrm{C}$,

$\mathrm{C}$ : Kulit luar manggis suhu $90{ }^{\circ} \mathrm{C}$,

$\mathrm{D}$ : Kulit luar manggis suhu $100{ }^{\circ} \mathrm{C}$

E : Kulit dalam manggis suhu $70{ }^{\circ} \mathrm{C}$,

$\mathrm{F}$ : Kulit dalam manggis suhu $80^{\circ} \mathrm{C}$,

$\mathrm{G}$ : Kulit dalam manggis suhu $90^{\circ} \mathrm{C}$,

$\mathrm{H}$ : Kulit dalamr manggis suhu $100{ }^{\circ} \mathrm{C}$

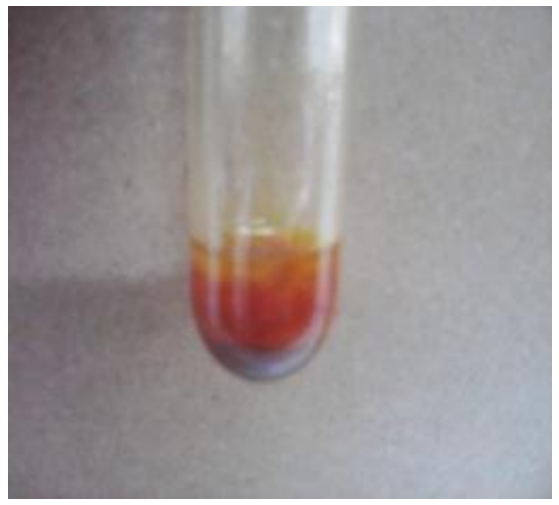

Dragendorff Endapan Merah Bata (+)

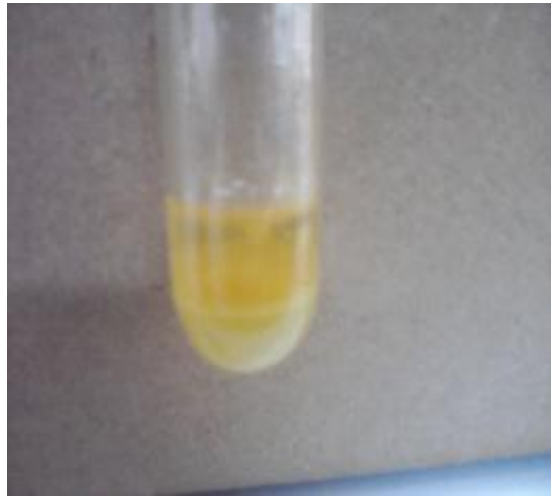

Mayer Endapan Putih (+)

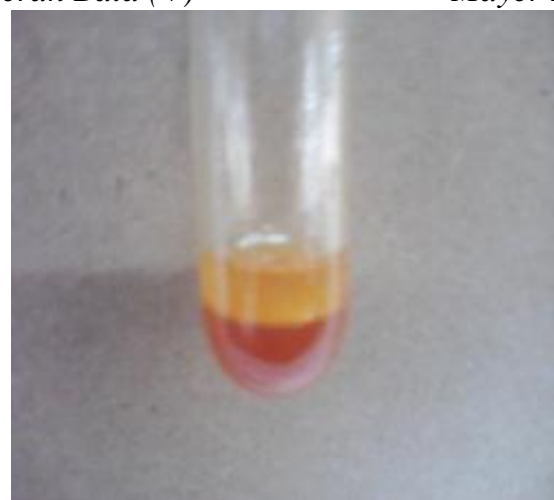

Wagner Endapan Coklat (+)

Gambar 2. Hasil Identifikasi Senyawa Alkaloid pada Pelarut Etanol 96\% 
Tabel 2. Identifikasi Senyawa Alkaloid pada Pelarut Etanol 96\%

\begin{tabular}{ccccc}
\hline SAMPEL & $\begin{array}{c}\text { DRAGENDORFF } \\
\text { Endapan merah } \\
\text { bata } \\
(+)\end{array}$ & $\begin{array}{c}\text { MAYER } \\
\text { Endapan } \\
\text { putih } \\
(+)\end{array}$ & $\begin{array}{c}\text { WAGNER } \\
\text { Endapan } \\
\text { coklat } \\
(+)\end{array}$ & $\begin{array}{c}\text { LARUTAN } \\
\text { BENING/KERUH }\end{array}$ \\
\hline A & ++ & ++ & + & KERUH \\
B & +++ & +++ & +++ & BENING \\
C & +++ & +++ & +++ & BENING \\
D & + & +++ & +++ & KERUH \\
E & + & + & + & KERUH \\
F & +++ & +++ & +++ & BENING \\
G & + & + & +++ & KERUH \\
H & ++ & ++ & ++ & BENING \\
\hline
\end{tabular}

Ket. A : Kulit luar manggis suhu $70{ }^{\circ} \mathrm{C}$,

$\mathrm{B}$ : Kulit luar manggis suhu $80^{\circ} \mathrm{C}$,

$\mathrm{C}$ : Kulit luar manggis suhu $90^{\circ} \mathrm{C}$,

D : Kulit luar manggis suhu $100^{\circ} \mathrm{C}$

$\mathrm{E}$ : Kulit dalam manggis suhu $70{ }^{\circ} \mathrm{C}$,

$\mathrm{F}$ : Kulit dalam manggis suhu $80^{\circ} \mathrm{C}$,

$\mathrm{G}$ : Kulit dalam manggis suhu $90{ }^{\circ} \mathrm{C}$,

$\mathrm{H}$ : Kulit dalam manggis suhu $100^{\circ} \mathrm{C}$

-: Negatif , + : Positif, ++ : Positif sedang, +++ : Positif Kuat

Tabel 3. Identifikasi Flavonoid pada Pelarut Etanol 96\%

\begin{tabular}{ccc}
\hline Sampel & $\begin{array}{c}\text { Warna yang } \\
\text { terbentuk }\end{array}$ & $\begin{array}{c}\text { (+)kuning } \\
(++) \text { kuning pekat } \\
(+) \text { merah } \\
(++) \text { merah pekat }\end{array}$ \\
\hline A & Merah & + \\
B & Merah & ++ \\
C & Merah & + \\
D & Kuning & ++ \\
E & Kuning & + \\
F & Kuning & + \\
G & Kuning & + \\
H & Kuning & + \\
\hline
\end{tabular}

Ket. A : Kulit luar manggis suhu $70^{\circ} \mathrm{C}$,

B : Kulit luar manggis suhu $80^{\circ} \mathrm{C}$,

$\mathrm{C}$ : Kulit luar manggis suhu $90^{\circ} \mathrm{C}$,

$\mathrm{D}$ : Kulit luar manggis suhu $100^{\circ} \mathrm{C}$

E : Kulit dalam manggis suhu $70^{\circ} \mathrm{C}$,

$\mathrm{F}$ : Kulit dalam manggis suhu $80{ }^{\circ} \mathrm{C}$,

$\mathrm{G}$ : Kulit dalam manggis suhu $90^{\circ} \mathrm{C}$,

$\mathrm{H}$ : Kulit dalam manggis suhu $100^{\circ} \mathrm{C}$ 


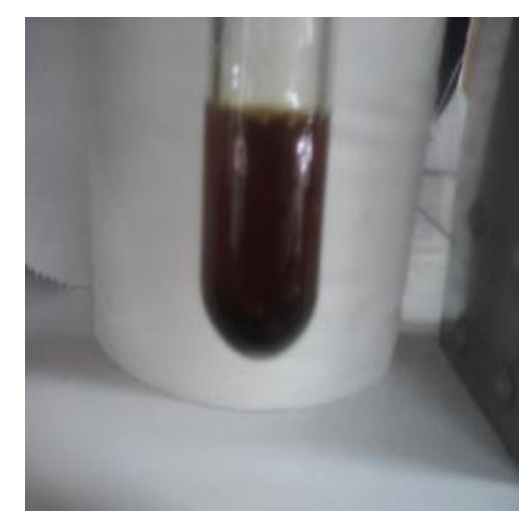

Merah (++)

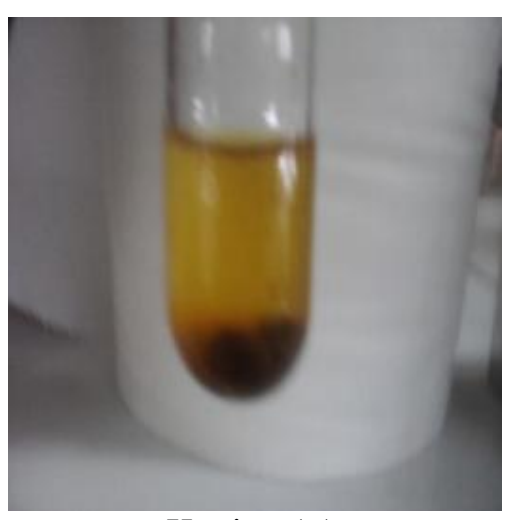

Kuning (+)

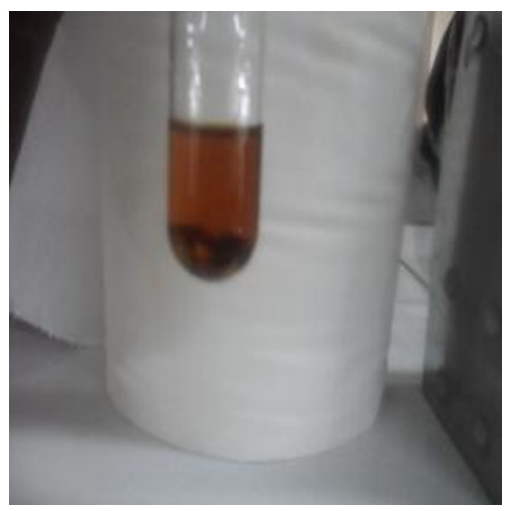

$\operatorname{Merah}(+)$

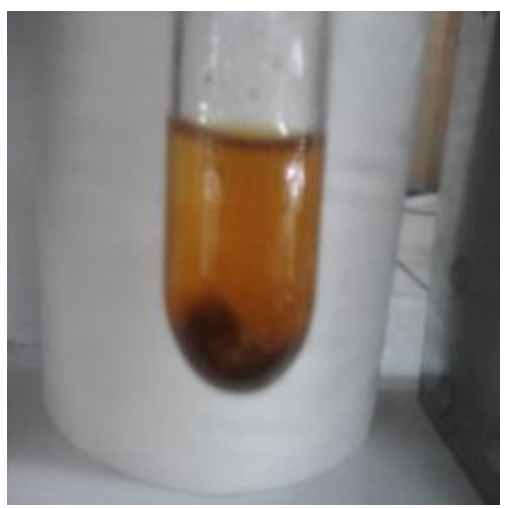

Kuning (++)

Gambar 3. Hasil Identifikasi Flavonoid pada Pelarut Etanol 96\%

Pada hasil identifikasi senyawa alkaloid dan flavonoid yang disajikan pada Tabel 2 untuk alkaloid, Tabel 3 untuk flavonoid dan hasil uji flavonoid dapat dilihat pada Gambar 3. Dapat dikatakan bahwa kulit manggis tahan akan temperatur tinggi terlihat dari hasil yang diperoleh terhadap kandungan dari kedua senyawa tersebut. Semua sampel menunjukkan hasil positif sebagai tanda dari adanya kandungan senyawa alkaloid dan flavonoid. Suhu pengeringan $80^{\circ} \mathrm{C}$ menunjukkan bahwa baik pada kulit bagian dalam maupun bagian luar ( B untuk kulit bagian luar dan $F$ untuk kulit bagian dalam) manggis menghasilkan kandungan senyawa alkaloid dan flavonoid yang lebih baik ditunjukkan dengan warna merah bata yang lebih pekat.Budidaya tanaman obat perlu dilakukan agar simplisia atau tanaman obat yang dihasilkan mempunyai ketersedian dan mutunya dapat terjamin.

\section{KESIMPULAN DAN SARAN}

\section{Kesimpulan}

1. Kulit manggis tahan terhadap suhu tinggi

2. Suhu pengeringan $80{ }^{\circ} \mathrm{C}$ memperlihatkan kandungan alkaloid dan flavonoid yang lebih baik pada kulit bagian dalam maupun bagian luar 


\section{Saran}

1. Perlu dilakukan penelitian kuantitatif untuk memperoleh hasil yang lebih optimal

2. Melakukan analisa dengan bahan baku yang seragam.

\section{DAFTAR PUSTAKA}

Harborne,J.B.1987.Phitochemical Methos. Chapman and Hall Ltd.London

Pramono, S. 2005. Penanganan Pasca Panen dan Pengaruhnya terhadap efek terapi obat alam. Seminar Nasional Tanaman Rempah dan Obat.

Balai Besar Penelitian dan Pengembangan Pascapanen Pertanian. Warta Penelitian dan Pengembangan Pertanian. Volume 32 Nomor 2, 2010 Jalan Tentara Pelajar No. 12A Bogor 16114

Sembiring,B.2007. Teknologi penyiapan Simplisia Terstandar Tanaman Obat.Warta Puslitbangbun Vol.13 No.2. Diakses tanggal 2 Desember 2011.

Supardjo.2010. Analisa Proksimat. Laboratorium Makanan Ternak. Fakultas Perternakan. Univ. Jambi.
Hadriyono. K.R.P. 2011.Karakter Kulit Manggis, Kadar Polifenol dan Potensi Antioksidan Kulit Manggis (Garcinia mangostana l.) Pada Berbagai Umur Buah dan Setelah Buah Dipanen.Skripsi. Dep. Agronomi Dan Hortikultura Fak Pertanian,IPB .

Marisi, R. T.,Soediro Soetarno,Elin Yulinah S. 2007 Telaah Kandungan Kimia dan Aktivitas Antimikroba Kulit Buah Manggis (Garcinia MangostanaL., Guttiferae). Sekolah Farmasi ITB http://bahan-alam.fa.itb.ac.id

Sembiring, B. 2007. Simplisia. Warta Puslitbangbun Vol.13 No. 2, Agustus 2007). Diakses tanggal 2 Desember 2011

Wong, Cathy, 2006. Mangosteen Alternative Medicine.Update July 19,2006. Diakses tanggal 2 Desember 2011.

Zhang Ze-sheng,Zhao Lu,Mu Hao,Suo Mao-rong.2009. Study on Extraction and Purification of The flavonoids from Garcinia mangostana L Pericarp. Jurnal, Food Research and Development (College of Food Engineering and Biological Technology,Tianjin University of Science \& Technology, Tianjin 300457, China. 